\title{
Methodology of determining the input data of control algorithms for a compression-ignition engine
}

The engine control process is usually carried out based on array control algorithms with a fixed mesh size. Modification of control algorithms based on experimental test data requires the use of programs that make it possible to determine the control algorithm parameters. The article presents the methodology of determining the compression-ignition engine control algorithms. A custom computer program was presented, which was used to determine the control algorithm parameters. These control algorithms values were determined based on the results of experimental engine tests, and using the presented program. The parameters were introduced into the laboratory compression-ignition engine controller. The experimental tests performed on the engine, whose operation was managed by the programmed laboratory controller, confirmed the usefulness of the proposed methodology for determining input data of control algorithms.

Key words: CI engine, engine control, control algorithms, ECU

\section{Introduction}

Standard fuel supply systems, used in modern compression-ignition engines, include common rail injection systems that allow for multi-phase injection. Precise engine control (Fig. 1) allows achieving some positive effects, such as: increased engine power, noise and exhaust emission reduction, uniformity of engine operation, high combustion process quality in the engine [2-6].

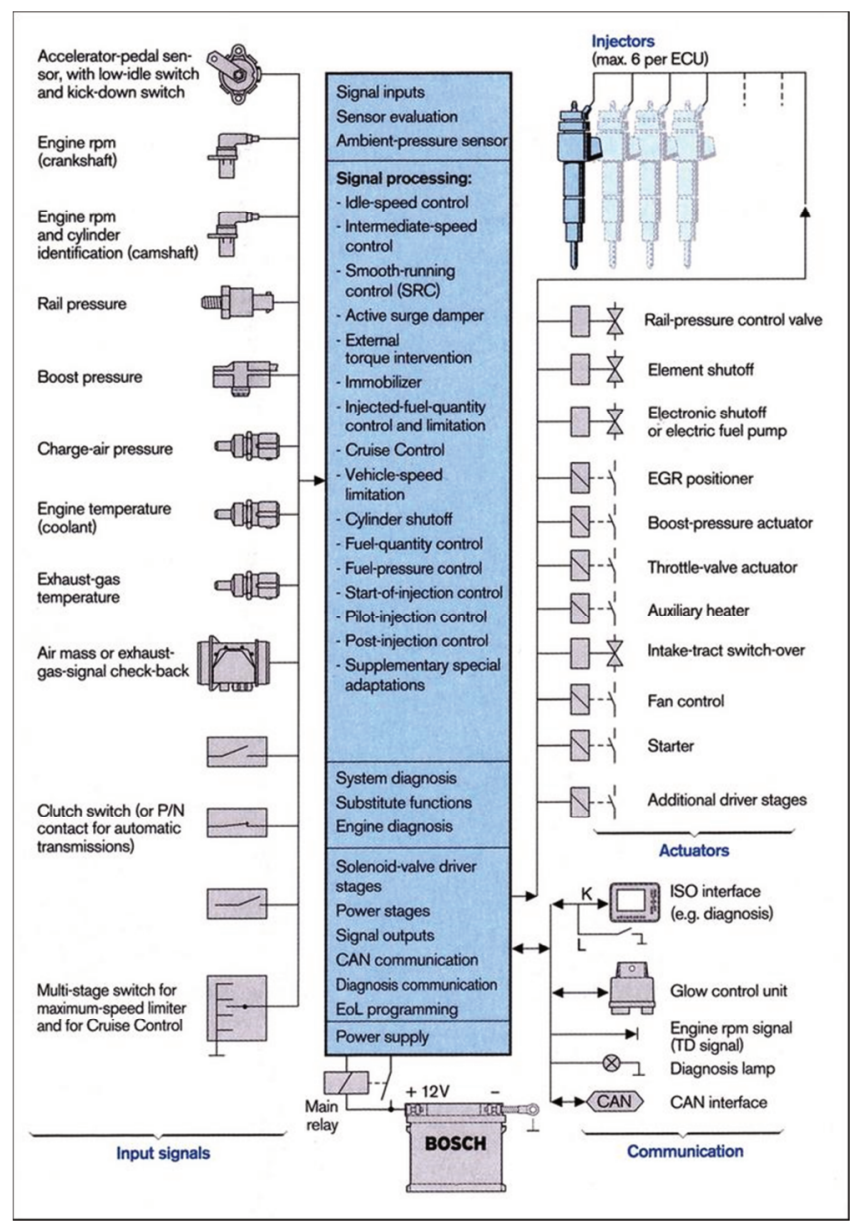

Fig. 1. An example engine control system used in a vehicle [12]
ECU power system controllers are able to adjust the fuel dose for each cylinder and shape the pressure in the combustion chamber by changing the fuel flow rate out of the injectors. Complicated and dependent control algorithms ensure quick and precise control of the engine's operation. Most often, the control algorithms are written in the form of one- or two-dimensional arrays $[1,10]$ depending on the parameter for which they are responsible. In the case of fuel injection process parameters, the algorithms are built based on two-dimensional arrays, usually presented graphically as so-called "Control maps" (Fig. 2).

The improvement of engine performance, or even the reduction of exhaust emissions are among the often accepted criteria in the research conducted on the selection of engine control parameters. The result of such research works is to obtain "new", "better" input data for the control algorithms, e.g. the fuel injection process in the compression-ignition engine. The implementation of this kind of experimental research is often very difficult when relying on factory engine controllers. Factory controllers, developed for a specific engine model, usually do not allow free modification of the engine operation parameters. Moreover, due to their complex structure, the number of registered and operational parameters reaching up to 3000 parameters and their interdependencies make them impossible to use in scientific research.

Therefore, it is advisable to equip the test bench with a less complicated controller taking into account the dependence of parameters that are important when the engine is mounted into the vehicle [7]. During the research on the selection of control algorithms parameters, it is necessary to have a controller, in which there will be no interdependent changes of some engine operation parameters due to changes being made in other parameters.

From previous experience $[8,9]$, the controller operating according to the above principles was developed in the Department of Combustion Engines and Vehicles of the University of Bielsko-Biala. The controller, as opposed to the factory controllers, enables the experimental tests to be carried out on the engine test bench taking into account the change of only the selected control parameter. In factory 
controllers, forcing a change in one parameter often leads to automatic changes in many other parameters of the engine control.

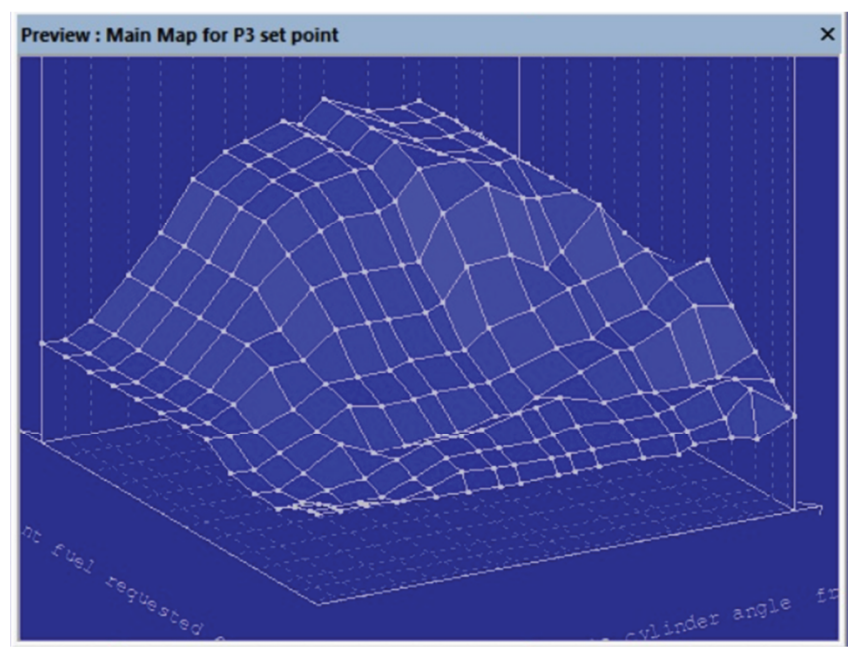

Fig. 2. An example of a „control map” for fuel supply [11]

The specific laboratory programmable controller of diesel engine with the Common Rail system was developed in cooperation with the MiSter company and is characterized by the following parameters:

- MCU controller (MiSter Control Unit) is built-in in a compact housing, input-output signals transferred through the standard engine bundle socket 1.3 SDE, no control buttons and displays on the housing,

- connection between the electronic system and the bundle socket enables modifying the output of individual signals from the controller as well as the input of parameters to individual pins in the socket. This is to ensure the possibility of using the controller for various factory engine bundles,

- the process of setting and monitoring the engine operating parameters is carried out by a PC controller management program (the controller is connected directly to the engine bundle on the test bench,

- MCU software enables monitoring, controlling and archiving defined parameters,

- the controller allows to divide the dose into 5 parts,

- input parameters (sensors and test bench system),

- output parameters (engine control).

\section{Program for determining the parameters of control algorithms}

As mentioned in the introduction, engine controllers operate based on the data contained in the arrays. These arrays must contain values corresponding to the initially accepted values of the control parameters, e.g. rotational speed and load, mesh division. Such selected engine operating points usually do not correspond to the points obtained during engine tests (Fig. 3). This is the reason behind the appearance of an interpolation problem of the obtained test results, and their extrapolation, where the results of experimental tests do not cover the entire area of the ECU (except the dotted line).

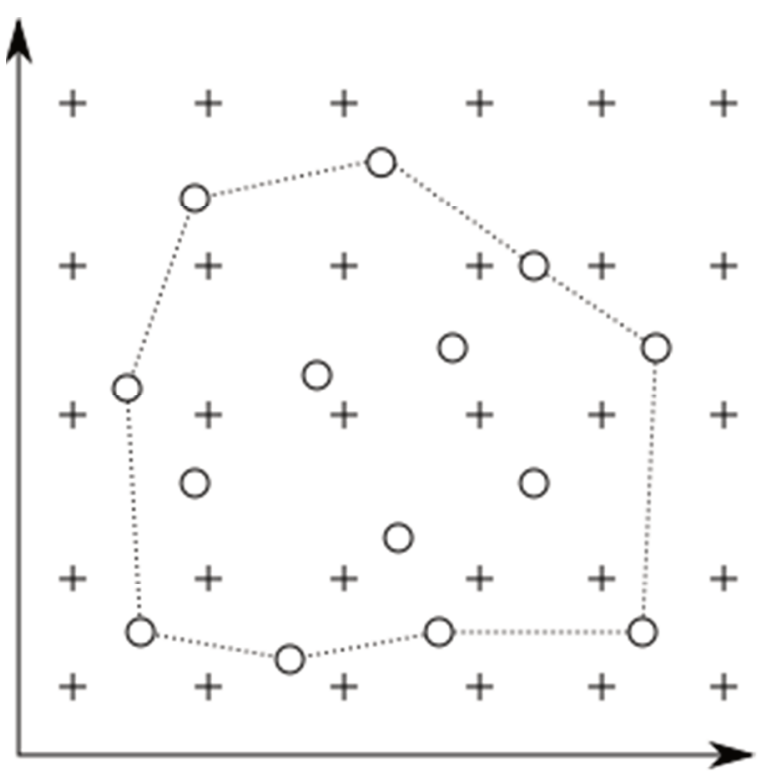

Fig. 3. The distribution of measuring points (circles) in relation to the points contained in the array (+)

The problem of interpolation can be easily solved by creating triangles based on measuring points. This makes it possible to easily determine the interpolated value inside the triangle. Unfortunately, there are many ways to create triangles based on the same set of points. Changing the triangle arrangement results in different interpolation results. In some cases, it is not possible to determine which result is correct and the differences can be very large. Figure 4 shows two ways of combining triangles giving different interpolated values $\mathrm{a}$ and $\mathrm{b}$.

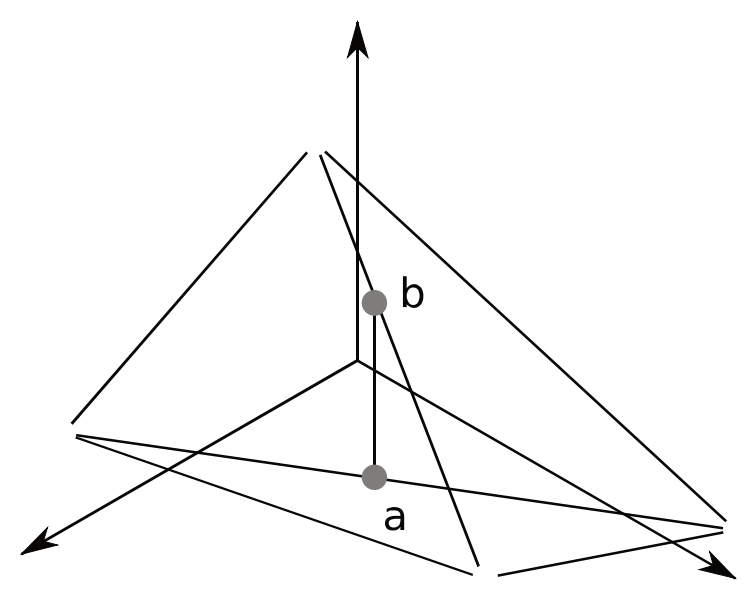

Fig. 4. Two different interpolation results dependent on the method of choosing the triangles

The problem becomes even more significant when extrapolated, because the triangles created may have different inclinations, which sometimes leads to results that make no physical sense.

For this reason, software has been created that does not require division into triangles. The method of determining points is based on interpolation of all measurement data on a plane (or a quadratic function). This plane is calculated independently for each determined point, where the meas- 
uring points are taken into account with different weights depending on the distance from the determined point. The weights of the measuring points decrease with the distance thanks to the bell curve (Fig. 5). This allows to uniquely determine the tangent plane to the designated map at any selected point, and using its equation also the location of the interpolated (or extrapolated) point. The only parameter influencing the obtained results is the width of the bell curve. It allows the adjustment of the degree to which the received map is smoothed out.

The presented method is quite complex computationally, however, due to the small number of points determined, the computation time does not exceed one second. Using the program, it becomes possible to quickly transform the experimental results into an array suitable for transfer into the ECU.

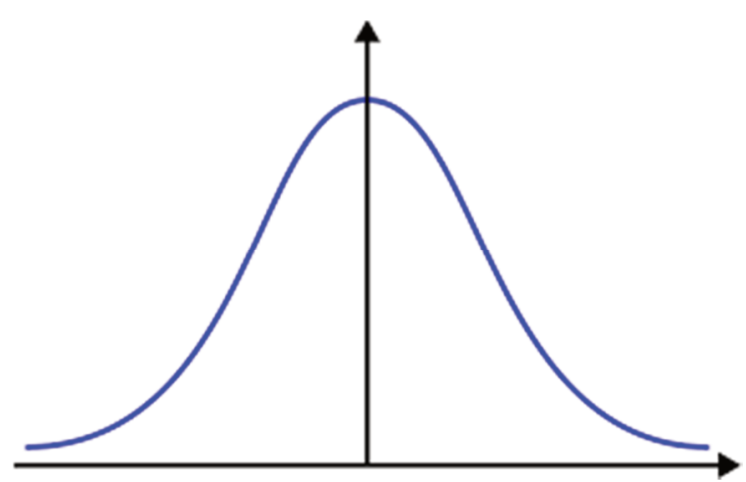

Fig. 5. Function defining the weights of the measuring points

Determining the input data of the control algorithms based on the developed program consists of loading the data file from experimental tests, specifying the desired mesh values and starting the calculation process. It is also possible to choose the type of isoline smoothing, as well as the Line/Square plot type.

Additionally, using the cursor, the values in individual points plotted on the graph presented in the program window can be read. The determined algorithm data can be saved by clicking the File tab, and Save.

\section{Base experimental tests}

\subsection{Research aim and shedule}

The aim of the basic research was to obtain the largest possible amount of information for the "factory" engine control, with particular emphasis on fuel dose distribution, dose size, injection timing for individual doses and injection pressure.

The obtained research material is the basis for the development of engine control algorithm parameters that will be used in the programming process of the laboratory controller.

The following engine tests on the engine test bench were performed for the base research:

- engine maximum power characteristic,

- engine idling characteristic,

- engine load characteristics.

The engine power characteristics were made in the range of 1000-4500 rpm every $250 \mathrm{rpm}$. The torque values used for the characteristic were used to select the engine load values when measuring the load characteristics.

The idling characteristics were made similarly to the engine power characteristics in the range of 1000-4500 rpm every $250 \mathrm{rpm}$, for the smallest possible load guaranteeing stable engine operation on the engine test bench. The idle characteristics together with the power characteristics determine the so-called range of engine operating parameters.

The engine load characteristics were determined in the engine speed range of 1000-4500 rpm every $500 \mathrm{rpm}, 8-10$ different load values for each of the rotational speeds. The loads were selected based on the power curve measured when the power characteristics were performed, in such a way that their values were alternated for neighboring rotational speeds.

\subsection{Test engine and the test bench station}

The test engine was a 1.3 SDE compression-ignition engine. The engine was equipped with an electronically controlled Common Rail system with a Multijet system that allows for fuel dose division in each working cycle. The engine's technical data is shown in Table 1. In basic tests, the engine control was carried out by the factory-provided MJD 6JX controller from Bosch.

Table 1. Technical data of the Fiat 1.3 MJT engine [19]

\begin{tabular}{|l|c|}
\hline Engine type & $1.3 \mathrm{MJT}$ \\
\hline Bore $\times$ stroke & $69.6 \times 82 \mathrm{~mm}$ \\
\hline Displacement & $1248 \mathrm{~cm}^{3}$ \\
\hline Number of cylinder & 4 \\
\hline Cylinder arrangement & straight \\
\hline Compression ratio & 18 \\
\hline Maximum power & $51 \mathrm{~kW}$ at $4000 \mathrm{rpm}$ \\
\hline Maximum torque & $180 \mathrm{Nm}$ at $1750 \mathrm{rpm}$ \\
\hline Injection system & Common Rail \\
\hline Number of valve per cylinder & 4 \\
\hline Timing system & DOHC \\
\hline Exhaust gas recirculation & Electric EGR valve \\
\hline
\end{tabular}

The basic research was carried out on the test bench (Fig. 6) in the laboratory of the Department of Combustion Engines and Vehicles at the University Bielsko-Biala [2]. Dynamometer control as well as monitoring and acquisition of test data was done by a fully automated test bench management system. The interface shown in Fig. 7 can be used to read parameters from the engine controller.

\section{Determining the control algorithm parameters}

Base results obtained in experimental research were recorded in tables in accordance with the requirements for preparing input data for the calculation program. In the calculations, a 20x20 array of algorithms was chosen. The rotational speed was selected in the range from 750 to 5500 rpm and accelerator handle signal in the range of 5 to $100 \%$. Numerical calculations were carried out, selecting the type of isoline smoothing several times, as well as the type of the graph to be used. The data obtained from the calculations were saved in the form of tables in the excel format. 


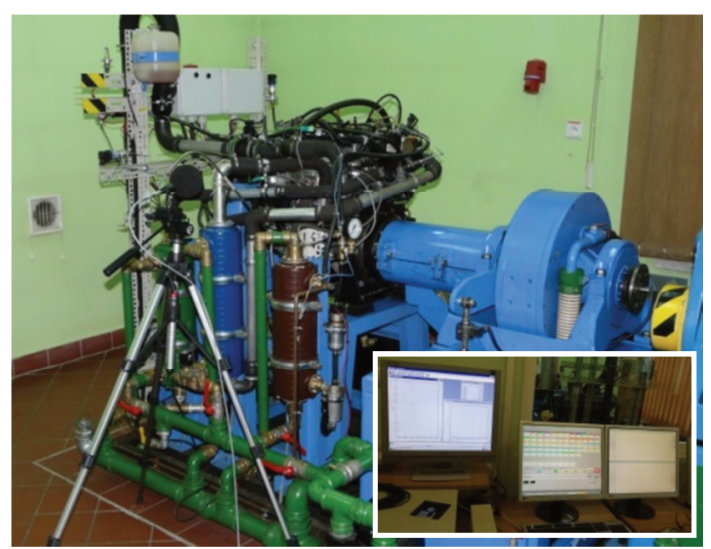

Fig. 6. The engine mounted on the dynamometer stand and the test bench management system monitors [7]

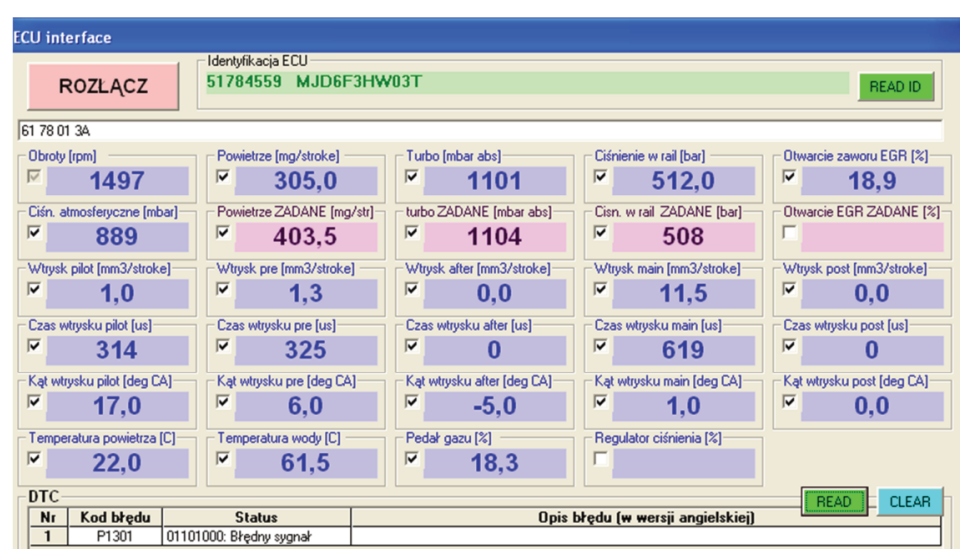

Fig. 7. Screenshot of the parameter monitoring interface window for the 1.3 SDE engine control [7]
Figures $8-11$ present a graphical interpretation of the control algorithms obtained for the selected parameters: fuel pressure in the rail, Pilot dose advance angle, Pre dose advance angle and Main dose advance angle. These parameters are presented in relation to the engine speed and the signal from the accelerator. The accelerator position is a parameter representing the given engine load.

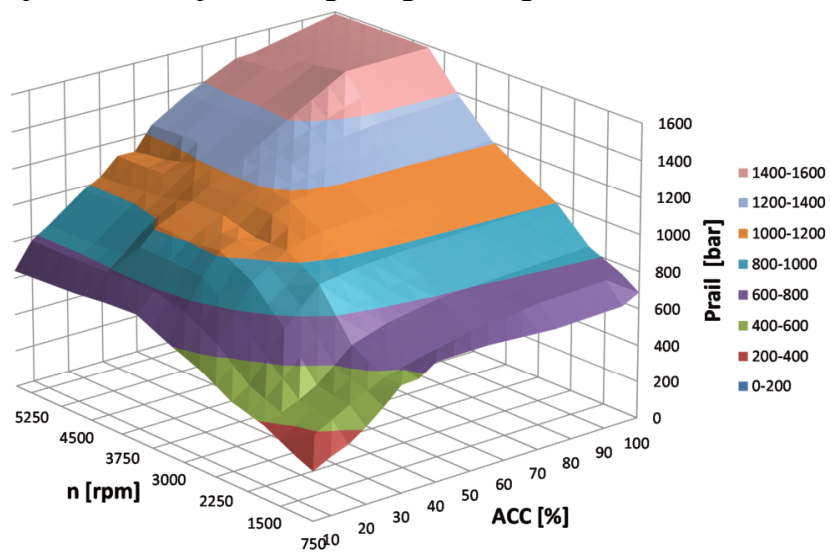

Fig. 8. Fuel pressure in the rail

Figure 8 shows the algorithm for determining the fuel pressure in the tank depending on the signal produced by the accelerator and the engine speed. The graph presents a relation in which the fuel pressure in the reservoir increases with the increase of the rotational speed and engine load. Fuel pressure increase is highest for low engine speeds and loads, as evidenced by the slope of the graph. Further on, the pressure increases in a more steady way (the plane flattens). The minimum fuel pressure in the manifold is 263 bar for minimum engine speed and load. Fuel pressure at the collector reaches a maximum value of 1590 bar for the engine speed value of $4000 \mathrm{rpm}$ and an accelerator position at $75 \%$. Despite the increase of the engine speed and the position of the accelerator, the fuel pressure value remains unchanged.

Figure 9 shows the algorithm for determining the injection advance angle for the Pilot dose depending on the load and rotational speed of the engine. The pilot dose is only used until the engine reaches $1750 \mathrm{rpm}$. The graph shows the interval in which the injection timing for the pilot dose changes. A decision was made to make the chart more transparent. Injection advance angle for the pilot dose increases as the load increases. As a function of engine speed, the advance angle increases initially, and in the range of 1500-1750 rpm it decreases. The maximum injection advance angle for the pilot dose occurs for the maximum load and the rotation speed of about $1500 \mathrm{rpm}$.

Figure 10 shows the algorithm for determining the injection advance angle for the Pre dose as a function of the accelerator and engine speed. The Pre dose only occurs until the engine reaches a speed of $4250 \mathrm{rpm}$. The algorithm

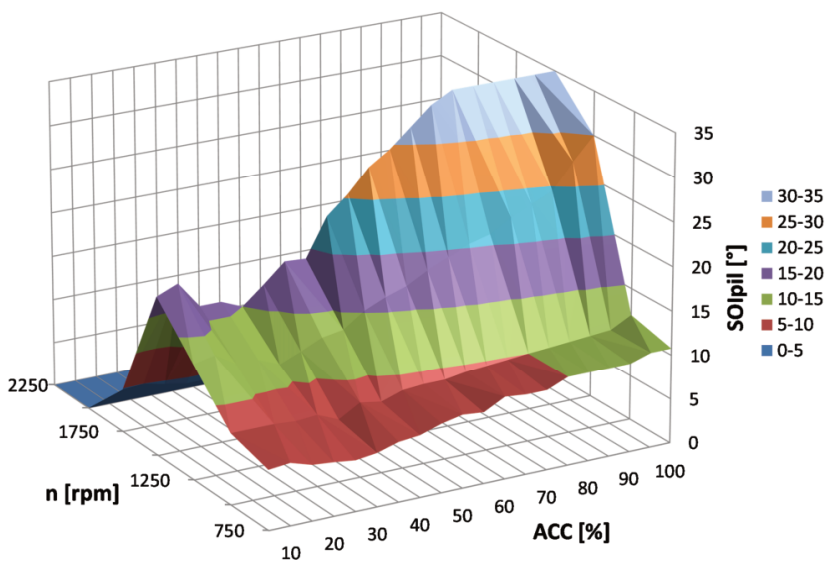

Fig. 9. Visual representation of the advance angle control algorithm for the Pilot dose

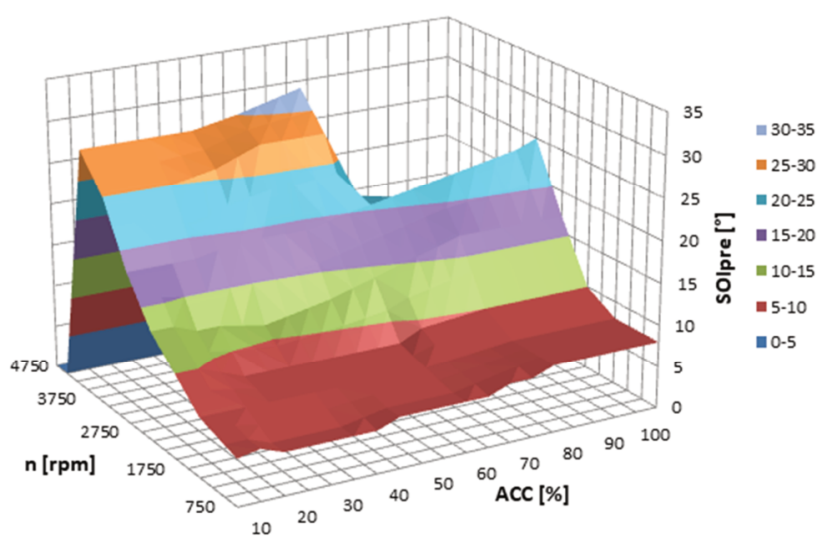

Fig. 10. Visual representation of the injection advance angle control algorithm for the Pre dose 
has two main parts. This is due to the absence of a Pre dose for a load greater than $70 \%$, starting at the engine rotational speed of $3500 \mathrm{rpm}$. The maximum injection advance angle for the Pre dose is $32^{\circ}$ on the crankshaft for a load of $55 \%$ and an engine speed of $4000 \mathrm{rpm}$.

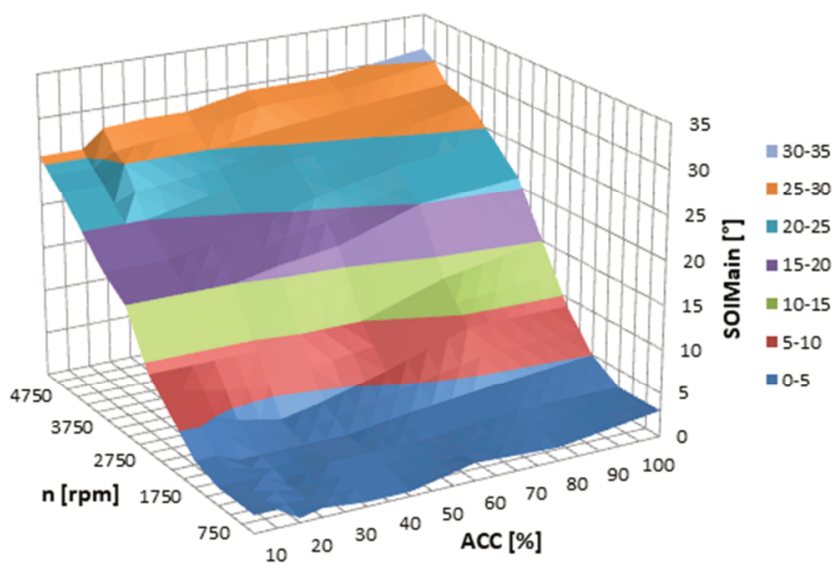

Fig. 11. Visual representation of the injection advance angle control algorithm for the Main dose

Figure 11 shows the algorithm for determining the injection advance angle for the Main dose depending on the signal of the accelerator and the engine speed. The Main dose, in contrast to the previous ones, is used for all values of engine load and speed. Analyzing the parameters of the determined algorithm, it can be noted that as the engine speed and load increase, the injection advance angle for the Main fuel dose also increases. For low engine speed values, the injection advance angle of the Main dose increases more slowly. In the central part of the graph, the plane has a higher incline, which is a result of a faster increase in the Main dose injection advance angle value. For speeds above $3750 \mathrm{rpm}$, the increase in the injection advance angle of the Main dose is losing its momentum. The minimum injection advance angle for the Main fuel dose is $1^{\circ}$ on the crankshaft at the minimum engine load and speed, while the maximum value of $31^{\circ}$ on the crankshaft occurs at maximum engine load and speed.

\section{Conclusion}

The result of the described research was the development of input data of selected engine control algorithms for a compression-ignition equipped with Common Rail fuel supply system in the entire engine operation range and acquiring a significant amount of engineering knowledge in relation to the electronic control of the modern compression-ignition engines. The developed computer program very quickly performs calculations, so it can carry out a wide range of calculations by changing the interpolation parameters. The proposed method of interpolation and extrapolation ensures a very high mapping accuracy of calculated data in relation to the input data. The designated data does not contain random errors, as was the case with the use of the triangles method in the initial versions of the program. The quality of calculations is confirmed by the smooth change of parameters as can be seen on the visual representation charts. None of the calculated algorithms have produced significant local increases or decreases in value, which would not make physical sense in relation to the changing control parameters.

The developed algorithms correlate with the algorithms of the factory engine controller. It can be expected that running the engine with a laboratory controller with programmed algorithms would enable the engine to operate in the entire range of its possible parameters. It should be kept in mind that the number of experimental input data and the distribution of these data against the background of the engine's range of operation have a decisive impact on the calculation quality of the control algorithm parameters.

The methodology for calculating algorithm parameters of the laboratory controller presented in the article is universal and can be used for programming the factory provided engine controllers as well.

\section{Nomenclature}

ACC

ECU

Main

$\mathrm{n}$

Pilot

accelerator
engine control unit
main fuel dose
engine speed
pilot fuel dose

accelerator

engine speed

pilot fuel dose

$\begin{array}{ll}\text { Prail } & \text { fuel pressure } \\ \text { Pre } & \text { preceding fuel dose } \\ \text { SOIpil } & \text { advance angle of the pilot injection } \\ \text { SOIpre } & \text { advance angle of the pre injection } \\ \text { SOImain } & \text { advance angle of the main injection }\end{array}$

\section{Bibliography}

[1] BOGUTA, A. Elektroniczna modyfikacja parametrów pracy silnika samochodowego o zapłonie samoczynnym. Motrol. 2011, 13, 21-27.

[2] CZAJKA, J., WISŁOCKI, K., PIELECHA, I., BOROWSKI, $P$. Examination of the influence of multi-injection strategy on thermodynamic indexes of engine cycle and on the emission of toxic compounds. Combustion Engines. 2014, 157(2), 45-59.

[3] HENNEK, K., PRAŻNOWSKI, K., BIENIEK, A. Wpływ modyfikacji map sterowania silnikiem na wybrane wskaźniki jego pracy. TTS Technika Transportu Szynowego. 2015, 12, 631-635.
[4] HETMAŃCZYK, I., HEPNER, W., HALICKI, R. Modyfikacja charakterystyki zewnętrznej silnika o zapłonie samoczynnym poprzez zmianę parametrów wtrysku paliwa. Inżynieria rolnicza. 2013, 2(143), 79-89.

[5] NOWAKOWSKI, J. Wpływ parametrów regulacyjnych silnika ZS na wybrane wskaźniki pracy. Combustion Engines. 2011, 146(3), 1-6.

[6] PIELECHA, I., BOROWSKI, P., CIESLIK, W. Investigations into high-pressure diesel spray-wall interaction on reduction of exhaust emission from DI diesel engine. SAE Technical Paper. 2014, 2014-01-1250. DOI: 10.4271/2014$01-1250$ 
[7] PIETRAS, D. Studium sterowania wieloczęściowym wtryskiem paliwa w silniku o zapłonie samoczynnym w aspekcie parametrów pracy silnika. Wydawnictwo Naukowe Akademii Techniczno-Humanistycznej w Bielsku-Białej. Bielsko-Biała 2019.

[8] STELMASIAK, Z., KNEFEL, T., LARISCH, J. Sterowniki do badań silników z systemem wtrysku Common Rail. Pomiary, Automatyka, Kontrola. 2010, 56(3), 217-220.

[9] STELMASIAK, Z., LARISCH, J., PIETRAS, D. Selection of an algorithms controlling operation of supercharged com-

Dariusz Pietras, DEng. - Faculty of Mechanical Engineering and Computer Science, University of Bielsko-Biala.

e-mail: pietras@ath.bielsko.pl

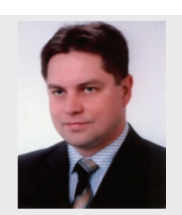

Konrad Czarniecki, MEng. - BOSMAL Automotive Research and Development Institute Ltd., BielskoBiala.

e-mail: konrad.czarniecki@bosmal.com.pl pression ignition engine with additional fueling with CNG gas. Combustion Engines. 2017, 170(3), 42-48. DOI: 10.19206/CE-2017-307

[10] STYŁA, S. Komputerowy model dydaktyczny elektronicznego układu sterowania silnikiem o zapłonie samoczynnym. Autobusy. 2018, 12. DOI: 10.24136/atest.2018.474

[11] http://www.vtechpomorze.pl/aktualnosci.html?page_a17=8

[12] http://www.autospeed.com/cms/article.html?\&title=CommonRail-Diesel-Engine-Management-Part-2\&A=108105

Marek Praszkiewicz, DEng. - Faculty of Mechanical Engineering and Computer Science, University of Bielsko-Biala.

e-mail: mpraszkiewicz@ath.bielsko.pl 